УДК 342.9 (477)

DOI https://doi.org/10.32849/2663-5313/2020.2.41

\title{
Михайло Тернущак,
}

канд. юрид. наук,

доцент кафедри адміністративного права і прочесу, фінансового та інформащійного права ДВНЗ «Ужгородський начіональний університет»

\section{ВПЛИВ АДМІНІСТРАТИВНОЇ РЕФОРМИ ТА ІНШИХ ГАЛУЗЕВИХ РЕФОРМ НА ТЕОРІЮ АДМІНІСТРАТИВНО-ПРАВОВИХ ДИСЦИПЛІН}

У статті проаналізовано вплив заходів адміністративної та інших галузевих реформ на теорію адміністративно-правових дисциплін. Розглянуто заходи правового, інституиійного та організаиійного змісту, шо реалізуються в рамках децентралізаиії, реформи публічної служби, судової, антикорупиійної, сервісної та інших реформ. Констатовано, що адміністративна реформа - ие процес прийняття належної нормативно-правової бази, що сприятиме формуванню такої системи органів публічного управління, яка повністю задовольнятиме публічний інтерес суспільства, тобто основним пріоритетом їхньої діяльності буде служіння народу та начіональним інтересам держави. У більш вузькій інтерпретаиії адміністративна реформа - ие комплекс нормативно-правових та організаиійних заходів, спрямованих на оновлення адміністративно-правового статусу суб'єкта реформування (адміністративного чи іншого органу) шляхом оптимізаиіі чисельності службовиів, удосконалення відомчої координачії взаємодії структурних підрозділів на иентральному та регіональному рівнях, удосконалення електронного, інформачійного та матеріального забезпечення працівників, спрощення прочедур надання адміністративних послуг та інше. Визначено, що питання правового забезпечення адміністративної та інших галузевих реформ є актуальним, враховуючи ефективність відповідних реформ, яка прямо залежить від якості законотворчого проиесу та з огляду на політику держави щодо удосконалення практик публічного адміністрування, відправлення судівництва та боротьби з корупчією. Визначено основні періоди сучасного етапу (2004-2020) адміністративної реформи: периий - реформа інституту адміністративної юстииї (2004 р. - прийняття Кодексу адміністративного судочинства України, 2017 р. - прийняття Закону України «Про внесення змін до Господарського процесуального кодексу України, Цивільного процесуального кодексу Украйни, Кодексу адміністративного судочинства України та інших законодавчих актів»); другий - формування нового інституту адміністративного права - інституту адміністративних послуг (2012 p. - прийняття Закону України «Про адміністративні послуги»); третій - реформа інституту публічної служби (2016 p - прийняття нового Закону України «Про державну службу»); четвертий - реформа судоустрою, судочинства та суміжних правових інститутів (2016 р. - внесення змін до Конституціі України (щодо правосуддя)); п'ятий - адміністративно-територіальна реформа (децентралізація у частині добровільного об'єднання територіальних громад (2015 р. - прийняття Закону Украйни «Про добровільне об'єднання територіальних громад»)).

Ключові слова: адміністративна реформа, публічна адміністрація, децентралізація, правові заходи, дисципліни адміністративно-правового циклу.

Постановка проблеми. Нині у рамках обраного європейського вектора розвитку Українська держава розпочала проводити реформи практично в усіх сферах публічного адміністрування, а також започаткувала реформу судоустрою, судочинства та суміжних правових інститутів. Зазначимо, що успіх реалізації відповідних реформ як прямо, так і опосередковано залежить від комплексного підходу запровадження заходів правового й організаційного характеру, міжвідомчої координації всіх гілок влади, об'єктивного суспільно-громадського контролю та повної аполітичності керівництва держави.
Нині в Україні триває масштабна адміністративна реформа, яка практично торкнулася всіх сфер публічного управління. Йдеться про децентралізацію, реформу публічної служби, судову, антикорупційну, сервісну та інші реформи. Кожен з перелічених напрямів адміністративної реформи потребує розробки та реалізації комплексу належних заходів правового, інституційного та організаційного змісту.

Проблематика реалізації адміністративної та інших правових галузевих реформ широко досліджувалася відомими вітчизняними вченими-адміністративістами, серед яких варто 
виділити В.Б. Авер'янова, Ю.П. Битяка, В.К. Колпакова, В.Т. Білоуса, Т.О. Коломоєць, О.В. Кузьменка, В.В. Галунька, Я.В. Лазура, О.В. Музи та інших. Проте саме питання впливу адміністративної реформи на теорію адміністративно-правових дисциплін предметом окремого наукового пошуку не виступало.

Мета статті полягає у дослідженні впливу адміністративної та інших галузевих реформ на теорію дисциплін адміністративно-правового циклу, зокрема визначенні змістового наповнення адміністративного права та процесу.

Виклад основного матеріалу. Вперше на державному рівні мета та завдання адміністративної реформи були сформульовані в Указі Президента «Про заходи щодо впровадження Концепції адміністративної реформи в Україні», що визначав адміністративну реформу, з одного боку, у комплексній перебудові наявної в Україні системи державного управління всіма сферами суспільного життя. 3 іншого - у розбудові деяких інститутів державного управління, які Україна ще не створила як суверенна держава. Мета адміністративної реформи визначалася як поетапне створення такої системи державного управління, що забезпечить становлення України як високо розвинутої, правової, цивілізованої європейської держави з високим рівнем життя, соціальної стабільності, культури та демократії, дасть змогу їй стати впливовим чинником у світі та Європі, а також формування системи державного управління, яка відповідатиме потребам і запитам людей, а головним пріоритетом її діяльності буде служіння національним інтересам українському народу.

Основними завданнями адміністративноправової реформи в Україні тоді були:

- формування ефективної організації виконавчої влади як на центральному, так і на місцевому рівнях управління;

- формування сучасної системи місцевого самоврядування;

- запровадження нової ідеології функціонування виконавчої влади і місцевого самоврядування як діяльності щодо забезпечення реалізації прав і свобод громадян, надання державних та громадських послуг;

- організація на нових засадах державної служби та служби в органах місцевого самоврядування;

- створення сучасної системи підготовки та перепідготовки управлінських кадрів;

- запровадження раціонального адміністративно-територіального устрою [1].

На вебпорталі Великої української енциклопедії адміністративна реформа трак- тується як вид державно-управлінської реформи, щодо змісту якої є три основні тлумачення.

Перше тлумачення зводить адміністративну реформу виключно до перетворень виконавчої влади, зокрема ï організаційної структури, функцій, форм і методів діяльності, кадрового забезпечення, а також взаємин із місцевим самоврядуванням. Зокрема, адміністративна реформа є комплексом узгоджених заходів, спрямованих на системну перебудову органів виконавчої влади, запровадження досконаліших форм і методів їх діяльності.

Друге тлумачення адміністративної реформи передбачає комплекс реформаторських заходів, що охоплює зміни за такими напрямами, як: структура системи органів виконавчої влади та розподіл функцій у ній; форми і методи діяльності органів виконавчої влади; державна служба; внутрішній контроль у системі виконавчої влади; адміністративна юстиція як поєднання діяльності адміністративних судів та спеціальних органів виконавчої влади; адміністративне законодавство.

Третє тлумачення базується на розгляді системи органів виконавчої влади та системи органів місцевого самоврядування як єдиного цілого - системи публічної адміністрації. Відповідно, адміністративна реформа передбачає реформування публічної адміністрації, зокрема зміни системи виконавчої влади, перетворення системи місцевого самоврядування, модернізацію адміністративно-територіального устрою, удосконалення співвідношення централізації та децентралізації, реформування державної служби та служби в органах місцевого самоврядування, розвиток системи зовнішнього, передусім судового, контролю за органами виконавчої влади та місцевого самоврядування, перегляд взаємин цих органів з громадянами, перетворення адміністративного законодавства [2].

Набагато стисліше адміністративну реформу інтерпретує В.Б. Авер'янов, на погляд якого, відповідна реформа є цілісним комплексом узгоджених заходів, спрямованих на радикальну перебудову органів виконавчої влади і запровадження ефективніших форм і методів їхньої діяльності [3].

Професор Ю.П. Битяк досить влучно наголошує, що адміністративна реформа проводиться не завжди комплексно і послідовно. Вчений виділяє низку проблем в організації та функціонуванні державного механізму: неопрацьованість системи стримувань і противаг, яка мала б забезпечувати збалансованість та єдність цього механізму, адже 
й досі залишається відкритим питання чіткого правового механізму подолання протиріч між різними гілками влади; подвійність центру керівництва діяльністю системи центральних та місцевих органів виконавчої влади; недоліки системи територіальної організації влади; громіздкість та неефективність адміністративно-територіального устрою держави [4].

В.В. Галунько вказує, що сучасні напрями розвитку адміністративної реформи в Україні характеризуються трьома рівнями: основоположним, загальним та спеціальним. Перший визначає, що по суті адміністративна реформа в Україні має здійснюватися у трьох взаємопов'язаних напрямах: реформи виконавчої влади; реформи місцевого самоврядування; реформи адміністративно-територіального устрою України. Другий дає відповіді, як розв'язати проблеми законодавчого супроводу та загальних організаційних шляхів її забезпечення. Третій визначає конкретні пріоритети здійснення адміністративної реформи, зокрема: розвитку засад громадянського суспільства, забезпечення прав і свобод людини та громадянина, забезпечення прогресивного розвитку сфери господарювання, місцевого самоврядування посилення, розвитку міжбюджетних відносин, запобігання та протидії корупції, забезпечення профілактики правопорушень [5].

Водночас В.В. Заблоцький зазначає, що якщо говорити про адміністративну реформу, то доцільно було казати не про адміністративну реформу, а про реформу публічної влади, тому що під терміном «адміністративна реформа» науковець розуміє реформу системи державного управління. Отже, якщо поглянути на фактичне реформування, то, на його переконання, ми вийшли за ці межі, адже реформуванню підлягає не лише система державного управління, а й система місцевого самоврядування [6].

Слід констатувати, що натепер багато що зроблено та запроваджено, особливо у площині правового забезпечення адміністративної реформи. Так, у рамках децентралізації прийнято Закон «Про добровільне об'єднання територіальних громад», ухвалено Концепцію розвитку місцевого самоврядування (2014), внесено зміни до Закону «Про місцеве самоврядування» у частині залучення громадськості до процесу прийняття рішень, напрацьовуються зміни до Конституції України щодо зміни адміністративно-територіального устрою. Закон «Про добровільне об'єднання територіальних громад» започаткував процес оновленої децентралізації на засадах поліцентричності, субсидіарності та фінансової незалежності.
Між тим активно напрацьовуються зміни до Конституції щодо децентралізації. Останнім законопроєктом є проєкт Закону «Про внесення змін до Конституції України (щодо децентралізації влади)» від 13.12.2019 № 2598, внесений Президентом. Відзначимо, що до цього Президент передавав до ВРУ проєкт Закону «Про внесення змін до Конституції України (щодо територіальної організації влади)» від 03.11.2019.

Так, реформа децентралізації передбачає передачу повноважень, фінансів на їх реалізацію та відповідальності за їх виконання від центральної влади органам місцевого самоврядування (ОМС), тобто керівництву (місцевим радам та їх головам), яке жителі територіальних громад самі собі виберуть. Отже, мета децентралізації - наближення влади до мешканців, а мешканців - до влади для підвищення доступності та якості освітніх, медичних, культурних, адміністративних, комунальних і соціальних послуг, які отримують ті самі мешканці громад [7]

По суті, реалізація відповідної реформи полягатиме у подальшому об'єднанні територіальних громад сіл, селищ, міст у відповідності до принципів поліцентричності, субсидіарності та процедури, прописаної у положеннях Закону «Про добровільне об'єднання територіальних громад». Адже поступове об'єднання територіальних громад не тільки сприятиме оптимізації територіальної організації місцевої влади у частині заміни не досить спроможних адміністративно-територіальних одиниць самодостатніми, які повною мірою зможуть забезпечувати очікуваний належний рівень публічного управління на місцях, а й збільшуватимуться фінансові надходження у місцеві бюджети.

Загалом, процес добровільного об'єднання територіальних громад - це практична реалізація принципу субсидіарності, зміст якого полягає у можливості приймати самостійно рішення на рівні місцевої влади (муніципального органу ОТГ) щодо здійснення управління відповідно до компетенції влади ОТГ, а це такі сектори: освіта, медицина, адміністративні послуги, дороги, освітлення, водопостачання, сміття, благоустрій, забудова, безпека та інше [8]. Натепер в Україні сформовано 1030 ОТГ, у яких функціонує 4591 рада [9].

Зазначимо, що законодавець у 2014 році поряд із Законом «Про добровільне об'єднання територіальних громад» прийняв і Закон «Про співробітництво територіальних громад», в якому прописав механізм та форми консолідації зусиль співпраці територіальних громад, зокрема фінансування спільних проєктів для вирішення питань 
місцевого значення (Закон «Про співробітництво територіальних громад»). До такого роду актуальних питань місцевого значення належать: збір, утилізація та переробка сміття, забезпечення якісного централізованого водопостачання та водовідведення, ремонт та прибирання доріг, організація пасажирських перевезень, утримання пожежної охорони тощо [10].

Наприклад, сектор медицини в умовах децентралізації реформується згідно 3 «Календарним планом реформування системи фінансування охорони здоров'я та інших ключових змін, які відбуватимуться в медичній галузі в 2017-2020 роках», що передбачає реалізацію таких заходів:

- запровадження нової моделі фінансування для первинної медичної допомоги;

- створення правових основ для нової системи фінансування охорони здоров'я;

- створення єдиного національного замовника медичних послуг;

- створення єдиної електронної системи обміну медичною інформацією;

- перегляд уніфікованих клінічних протоколів для переліку найбільш поширених медичних станів і спрощення вимог до ведення паперової звітності у медичних закладах;

- запровадження нової моделі фінансування медичної допомоги для вторинної (спеціалізованої) та третинної (високоспеціалізованої) медичної допомоги. А $з$ 2018-го передбачається її запровадження в усіх закладах, що надають стаціонарну допомогу;

- створення госпітальних округів

- запровадження національної системи реімбурсації лікарських засобів для визначеного переліку медичних станів;

- автономізація бюджетних закладів охорони здоров'я [11].

Більше того, наступним етапом децентралізації має стати процес реорганізації місцевих державних адміністрацій та запровадження інституту префектури з повноваженнями нагляду за додержанням Конституції і законів України органами місцевого самоврядування, координації діяльності територіальних органів центральних органів виконавчої влади. Отже, реформа місцевого самоврядування перебуває тільки на початковій стадії, яка має завершитися укрупненням територіальних громад в Україні в межах нового адміністративно-територіального устрою, який також спрямований на укрупнення територіальних одиниць (регіонів, округів (повітів), громад). Попередній Міністр регіонального розвитку, будівництва та ЖКГ України Геннадій Зубко вказував, що в Україні за новою моделлю адміністративно-територіального устрою з 468 районів буде сформовано 102 [12].

Надалі планується ліквідувати місцеві державні адміністрації (обласні, районні) та створити інститут префектів, посадових осіб, що керуватимуть виконавчою владою на місцях із повноваженнями призупиняти дію, а у разі посягання на державний суверенітет скасування актів органів місцевого самоврядування.

Говорячи про децентралізацію, не можна оминати типи і форми децентралізації, 3 урахуванням яких реформувалося зарубіжне місцеве самоврядування. Зокрема, це такі типи: політичний, адміністративний та фіскальний; та форми: деконцентрація, деволюція, делегування. Натепер практика вітчизняного самоврядування дає змогу констатувати позитивні тенденції у сфері державної реєстрації щодо процедур реєстрації речових прав на рухоме та нерухоме майно, ФОП та юридичних осіб та місця проживання. Реєстраційні процедури починаючи з 2015 року були передані до компетенції муніципальних органів у рамках делегування від місцевих органів юстиції.

Реформа публічної служби зумовлена прийняттям нової редакції Закону «Про державну службу» (2016), що відповідає європейським стандартам. Прийняття нової редакції Закону «Про державну службу», де знайшли власне місце норми щодо зміни процедури вступу на державну службу у частинах введення обов'язкового конкурсного відбору, незалежності від категорій державних службовців та посилення контролю за його проведенням шляхом залучення громадськості та міжнародних експертів. Отже, цим Законом суттєво удосконалено процедури вступу на публічну службу та атестування державних службовців, оптимізовано кількість категорій та рангів державних службовців.

Однак не тільки зміна процедурних аспектів виступила передумовою реформування публічної служби. 3 цього приводу досить влучно висловились Т. Крушельницька, С. Ралдугін, В. Гусєв, В. Купрійчук, які стверджують, що адміністративне реформування має охоплювати i реформування державної служби і служби в органах місцевого самоврядування (публічної служби), де працюють державні службовці і посадові особи місцевого самоврядування, що пов'язано з такими факторами:

- неналежний компетентністний рівень кадрів

- покладання на державних службовців і посадових осіб місцевого самоврядування 
політичних функцій під впливом партійнополітичної доцільності, який може переважати на регіональному, місцевому рівнях а також вплив партії, яка перебуває при владі, на державних службовців і посадових осіб місцевого самоврядування;

- недосконалість системи підготовки перепідготовки та підвищення кваліфікації державних службовців і посадових осіб місцевого самоврядування [13, с. 9].

Крім того, планується у найближчий час прийняти нову редакцію Закону «Про службу в органах місцевого самоврядування», який є застарілим (2001) та не відповідає міжнародним стандартам самоврядування.

У межах правового регулювання судової реформи внесено зміни до Конституції шляхом прийняття Закону «Про внесення змін до Конституції України (щодо правосуддя)», прийнято нову редакцію Закону «Про судоустрій та статус суддів», внесено зміни до процесуальних кодексів (Закон «Про внесення змін до Господарського процесуального кодексу України, Цивільного процесуального кодексу України, Кодексу адміністративного судочинства України та інших законодавчих актів») та прийнято низку інших нормативно-правових актів, прийнято Закон «Про Вищий антикорупційний суд».

Правове забезпечення антикорупційної реформи зумовлене створенням блоку антикорупційних органів, таких як Національне антикорупційне бюро, Національне агентство з питань запобігання корупції, Вищий антикорупційний суд, та структурного підрозділу у складі на той час Генеральної прокуратури - Спеціалізованої антикорупційної прокуратури. Для повноцінного запуску та роботи кожного 3 відповідних органів потребувалася належна правова основа, наслідком чого стало прийняття законів «Про Національне антикорупційне бюро», «Про запобігання корупції», «Про Вищий антикорупційний суд», а також «Положення про Спеціалізовану антикорупційну прокуратуру Генеральної прокуратури України».

Реформа, пов'язана 3 удосконаленням процедур надання адміністративних послуг, розпочата у 2012 р. 3 моменту прийняття Закону «Про адміністративні послуги», активно запроваджується та реалізується практично в усіх територіальних органах виконавчої влади та місцевого самоврядування. Як правило, у вищезазначених органах функціонують як окремі структурні підрозділи чи робочі місця центри надання адміністративних послуг, діяльність яких розподілена за принципами «фронт та бекофісу» та «єдиного вікна».
Починаючи із 2013 р. в Україні реалізують і інші публічні реформи. Зокрема, реформа судоустрою, судочинства та суміжних правових інститутів (адвокатури, прокуратури, системи виконання покарань); реформа системи запобігання та протидії корупції (антикорупційна); реформа правоохоронної системи.

Питання правового забезпечення адміністративної реформи є актуальним, оскільки ефективність відповідної реформи прямо залежить від якості законотворчого процесу та є таким, що потребує поглибленого аналізу з огляду на політику держави щодо удосконалення практик публічного адміністрування, відправлення судівництва та боротьби з корупцією.

Окрім того, натепер з урахуванням напрямів адміністративної реформи, що проводилися та здійснюються, до основних періодів сучасного етапу (2004-2020) адміністративної реформи слід віднести:

1) реформу інституту адміністративної юстиції (2004 р. - прийняття КАСУ; 2017 р. прийняття Закону «Про внесення змін до Господарського процесуального кодексу України, Цивільного процесуального кодексу України, Кодексу адміністративного судочинства України та інших законодавчих актів»);

2) утворення нового інституту адміністративного права - інституту адміністративних послуг (2012р. - прийняття Закону «Про адміністративні послуги»):

3) реформу інституту публічної служби (2016 p. - прийняття нового Закону «Про державну службу»);

4) реформу судоустрою, судочинства та суміжних правових інститутів (2016 р. внесення змін до Конституції України (щодо правосуддя));

5) адміністративно-територіальну реформу (децентралізація у частині добровільного об'єднання територіальних громад (2015 р. прийняття Закону «Про добровільне об'єднання територіальних громад»)).

На думку Н. Гончарук, новий етап адміністративної реформи в Україні передбачає:

- впровадження нових ефективних моделей публічної адміністрації;

- створення раціональної та стабільної системи органів виконавчої влади не лише на центральному, але й на місцевому рівнях;

- здійснення ефективного розподілу функцій і повноважень між органами публічної влади та рівнями публічної адміністрації;

- децентралізацію надання адміністративних послуг громадянам та підвищення їх якості;

- забезпечення розвитку місцевого самоврядування; 
- створення професійної, політично нейтральної, відповідальної та авторитетної державної служби та служби в органах місцевого самоврядування;

- утвердження партнерських відносин між державою та громадянами [14]

Отже, на наш погляд, адміністративна реформа - це процес прийняття належної нормативно-правової бази, що сприятиме формуванню такої системи органів публічного управління, яка повністю задовольнятиме публічний інтерес суспільства, тобто основним пріоритетом їх діяльності буде служіння народу та національним інтересам держави. У більш вузькій інтерпретації адміністративна реформа являе собою комплекс нормативно-правових та організаційних заходів, спрямованих на оновлення адміністративно-правового статусу суб'єкта реформування (адміністративного чи іншого органу) шляхом оптимізації чисельності службовців, удосконалення відомчої координації взаємодії структурних підрозділів на центральному та регіональному рівнях, удосконалення електронного, інформаційного та матеріального забезпечення працівників, спрощення процедур надання адміністративних послуг та інше.

\section{Висновки}

Таким чином, вплив адміністративної реформи на теорію адміністративного процесу, а також адміністративного права зумовлений правовими, інституційними та організаційними змінами у діяльності органів публічної адміністрації, що є наслідком приведення вітчизняних практик публічного адміністрування до європейських стандартів, а також процедурними змінами щодо розгляду різних категорій адміністративних справ.

Відзначимо i вплив адміністративної реформи на уточнення змістового наповнення дисциплін адміністративно-правового циклу та трансформацію предметів адміністративного права та процесу, що, на наше переконання, відобразилося у введенні окремих спецкурсів, у яких поглиблено вивча- ються зміни адміністративно-процесуального законодавства у частині особливостей (специфіки) окремих адміністративних проваджень.

\section{Список використаних джерел:}

1. Про заходи щодо впровадження Концепції адміністративної реформи в Україні : Указ Президента України від 28.05.2006 № 810/98. URL: https://zakon.rada.gov.ua/rada/show/810/98.

2. Адміністративна реформа. URL: https://vue.gov.ua/.

3. Енциклопедія сучасної України. Адміністративна реформа. URL: http://esu.com.ua/ search_articles.php?id=42669.

4. Адміністративна реформа в Україні: пріоритети та механізми реалізації. URL: http://dspace. nlu.edu.ua/bitstream/123456789/1685/1/1.pdf.

5. Напрями адміністративної реформи в Україні. URL: file://C:/Users/admin/Downloads/ FP_index.htm_2011_1_37.pdf.

6. Адміністративна реформа: стан та перспективи трансформації. URL: http://www.dy.nayka. com.ua/?op=1\&z=868.

7. Децентралізація: коротко про головне. URL: http://cost.ua/news/698-detsentralizatsiyakorotko-pro-holovne.

8. Про об'єднання громад. URL: https://decentralization.gov.ua/gromadas.

9. Об'єднанні громади: перелік та основні дані. URL: https://decentralization.gov.ua/gromada.

10. Співробітництво громад. URL https://decentralization.gov.ua/cooperation.

11. Реформа медицини в умовах децентралізаціï. URL: https://decentralization.gov.ua/health.

12. Офіс Президента: нова адміністративна реформа передбачає скорочення органів влади. URL: https://www.unn.com.ua/uk/news/1813667ofis-prezidenta-nova-administrativna-reformaperedbachaye-skorochennya-organiv-vladi.

13. Адміністративна реформа в Україні: соціологічний вимір ставлення слухачів і працівників Національної академії у 2012 році : навчальні матеріали для самостійної підготовки. / Т.П. Крушельницька, Є.О. Алдугін та інші. Київ : НАДУ, 2013. 60 с

14. Адміністративна реформа в Україні: сучасний стан та перспективи. URL: file:///C:/Users/ admin/Downloads/508-Article\%20Text-695-1-1020190730.pdf.

The article analyzes the influence of administrative and othersectorre forms on the theory of administrativelegal disciplines. Considered measures of legal, institutional and organizational content implemented in the framework of decentralization, public service reform, the judiciary, anti-corruption, service and other reforms. It was noted that administrative reform is a process of adopting appropriate legal and regulatory framework that will facilitate the formation of such system of public administration authorities, which will fully satisfy the public interest of society, that is the main priority of their activities is the Ministry of the people and the national interests of the state. In a more narrow interpretation administrative reform is a complex of legal and organizational measures aimed at upgrading the administrative and legal status of the subject of reform (administrative or other authority) by optimizing the number of employees, improve departmental coordination of interaction of structural units at the Central and regional levels, improvement of electronic, information and material provision of employees, simplification of procedures and administrative services 
and more. Determined that the issues of legal provision of administrative and other sectoral reforms is relevant given the effectiveness of appropriate reforms, which directly depends on the quality of the legislative process and considering the policy of the state to improve practices of public administration, administration of justice and combating corruption. Identified key periods of the modern stage (2004-2020) administrative reform: first, the reform of the Institute for administrative justice (2004, the adoption of the Code of administrative procedure of Ukraine, 2017 the adoption of the Law of Ukraine "On amendments to Economic procedural code of Ukraine, Civil procedural code of Ukraine, code of administrative procedure of Ukraine and other legislative acts"); second, the formation of a new Institute of administrative law Institute for administrative services (2012 the adoption of the Law of Ukraine "On administrative services"); and third, reform of the Institute of public service (2016 adoption of the new Law of Ukraine "On state service"); fourth, reform of the judicial system, legal proceedings and related legal institutions (2016 amendments to the Constitution of Ukraine (justice)); fifth, administrative reform (decentralization in terms of voluntary unification of territorial communities (in 2015 the Law of Ukraine "On voluntary unification of territorial communities")).

Key words: administrative reform, public administration, decentralization, legal measures, disciplines, administrative law cycle. 